\title{
Black women's bodies as reformers from the dungeons: The Reformation and womanism
}

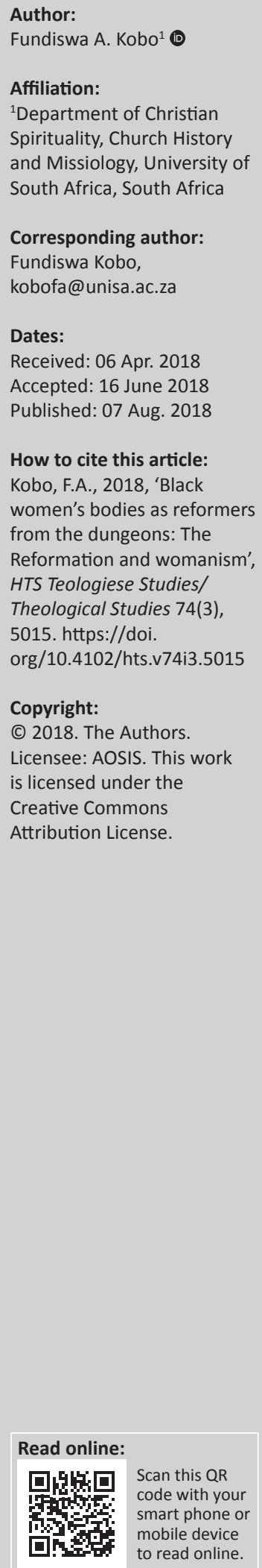

While it cannot be denied that the 16th-century Reformation, which challenged papal authority and questioned the Catholic Church's ability to define Christian moral practice in a just manner, indeed came with deep and lasting political changes, it remained a maledominated discourse. The Reformation was arguably patriarchal and points to a patriarchal culture of subordination and oppression of women that prevailed then and is still pertinent in the church and all spheres of society today. The absence of Elmina and the silenced yet loud voices and cries from the female dungeons below a Dutch Reformed Church in the upper levels of the castle in the retelling of the narrative of the Reformation leaves much to be desired and has a bearing on how black women perceive the Reformation 500 years later. The article thus problematises the Reformation through the heuristic eyes of Elmina Castle in Ghana as the genesis of the 'dungeoning' of black women justified by faith. The article argues that black women are reformers from the dungeons following the historical experience of reformation and the Reformed faith as racist and sexist, among other ills experienced by blacks in the Global South, with black women literally kept in the dungeons below a Reformed Church building as they were in Elmina with a biblical inscription, Psalm 138, on the threshold of its main door. This article thus points to irreconcilable contradictions maintained by the Reformed faith that continues to bury black women in the 'dungeons' even today. The enfleshment of black bodies in the dungeons of the Elmina Castle underneath a Reformed Church building is seen as the historical and heuristic starting point of engaging Reformed faith from a womanist perspective.

\section{Introduction}

This article was originally drafted for a conference of the Change Agency Project, a community engagement project of the Department of Christian Spirituality, Church History and Missiology, under the theme 'Reformation, Transformation and Change Agency', which marked the 500th anniversary of the Protestant Reformation. ${ }^{1}$ Before we proceed it might be important for me to state that the use of ' $\mathrm{I}$ ' or 'we' in my writing is an expression of a conversation that is never possible without others from a womanist perspective and a conscious statement against the Cartesian ego.

The time when this article is being written has been marked by shifts and in some instances questionable hope on the possibility of transformation of the Reformed tradition and church. Two incidents are worth noting that inspire the nuance of reformation and the Reformed tradition to which I belong, the first being my visit to Elmina Castle in Ghana in January 2018, which turned my belief system and spirituality upside down. However, the most recent consultation of Reformed Churches in Southern Africa in Benoni, South Africa, which I attended as the delegate of the Uniting Presbyterian Church in Southern Africa (UPCSA), left even deeper questions. I concur with Vellem (2013:4) when he argues, 'there can be no Reformed tradition in South Africa or Africa without contending with the distortions and death-dealing effects it has had [and continues to have] on this continent'. Our reflection on this topic, shaped by a personal experience of the visit to Elmina Castle in Ghana and the Benoni conference, begins by painting a picture of this castle and the place of a black woman in its dungeons. We then proceed to pose the question of whether the Reformation was racist and sexist and whether John Calvin was aware of Elmina and the dungeoning of black women. We proceed to look at the pervasive dungeons - dungeons both historically understood as a reality and heuristically used to connote the current condition for South African women post 1994 and the pseudo-spirituality of a Calvinist woman from the dungeons of Elmina.

1.The conference was held at the University of South Africa on 30 and 31 October 2017 . This article is thus a product of the reworking of the original one that was intended for the conference. 


\section{A womanist memory of Elmina}

I visited Elmina Castle ${ }^{2}$ for the first time in November 2015 and for the second time in January 2018. On both visits, I observed the structural oppression and commodification of black humanity as slaves. However, I was struck by the way in which this castle is structured and the location of enslaved black African women, who are arguably slaves among slaves, as they are oppressed more than their male counterparts and in some instances by them, as patriarchy is equally a challenge in Africa.

Upstairs you find the governor's and the merchants' quarters, barracks for soldiers and pastors, and the Dutch Reformed chapel is located on the same floor. Below are dungeons, male and female dungeons. One of the things the tour guide narrated was that women were often brought to the courtyard, and the governor, that is, the powerful male ruler, would select whom he found appealing for sexual exploitation, often subsequently to be raped by the slave traders. In some instances women were raped by guards; we also heard that some women resisted being raped and as a result they would be put in chains and deprived of food. It is hard to overlook this resistance by enslaved women, who would have known what the consequences would be. For us this spirit of resistance in such degrading conditions and the unwillingness of women to bow down to the perverse sexual desires of an enslaver is powerful powerlessness, a means in which they could speak under the circumstances and maintain their dignity.

In Elmina, one sees broken black African women's bodies! The touch of the cracked walls brings the feeling of their scars, visible and invisible. One smells their odour in those dungeons as though they were never cleaned. The smell of urine, faeces and menstrual blood is still there because these women were not allowed to leave the dungeons even to relieve themselves. They had to relieve themselves there, where they were kept. The only time they were bathed is when one of them was chosen on a particular day to satisfy the enslaver's sexual fantasies. Even then, she would be bathed in public, by water that was not used by the Dutch officials, who feared that it had been poisoned by the Portuguese, from whom they had inherited the castle. Our picture is that of seeing, feeling and smelling women who on daily basis wondered when their turn would come down there in the congested dungeons, where their bodies and minds would be violated and their souls crushed before they would be taken through the 'door of no return', to be sailed across the Atlantic, never to return to their motherland. The transatlantic slavery system ensured that they were kept there chained in dungeons. Indeed, the bodies of black African women are disfigured and deformed in many ways even today.

It is unavoidable in our reflection to note the 'close affinity of the Reformed faith with slavery' (Vellem 2013:2). The location

2.The castle was initially designed for gold and ivory trade but under the Dutch slave trade was added (http://www.everycastle.com/Elmina-Castle.html; viewed 04 April 2018). of a Dutch Reformed chapel above the female dungeon at Elmina Castle, where human beings were commodified, where human beings were starved to death when they resisted inhuman actions, where black African women were raped and humiliated, is a clear demonstration of how the church can allow itself to become the cultural and religious guardian of the symbols of domination and subjugation. Was John Calvin not aware of this? He must have known, we submit!

What Cone observed of Niebuhr, who was unable to make a connection between a lynching tree and the cross, is arguably the fundamental problem of the West in relation to grasping the ugliness of the dungeons for black women. ${ }^{3}$ The fact that John Calvin could not make a connection between his theology of social justice and slavery, racism and triple jeopardy of a black woman ${ }^{4}$ is telling, even more so to white Calvinists in South Africa, who later developed his teachings into an apartheid theology. Our point is that Calvin must have surely known about slavery, yet the enslavement of black people somehow eluded him! Who can enter Elmina Castle and come out? Some of us remain in the relics and residual experiences of Elmina, in Benoni, South Africa, in the UPCSA, as we will reflect later. A patriarchal and racist reformation is what one gets from Elmina and thus that is the framework within which our discussion takes place.

\section{A racist and/or sexist reformation?}

By this permutation, 'racist/sexist', we should not assume an either/or but a both/and rendition of the transversal nature of racism with all constructs of colonisation. Admittedly, the 16th-century Reformation challenged papal authority and questioned the Catholic Church's ability to define Christian practice. It arguably came with deep and lasting political changes (History.com Staff 2009). The absence of women in the telling of the story points to a patriarchal culture of subordination and oppression of women that prevailed then and is still pertinent in the church today (Giselbrecht 2014: ii-iii). Bowie, Kirkwood and Ardner (1994:1) assert that '[i]n being seen as adjuncts to men, rather than as historical protagonists in their own right, women have been systematically written out of the historical and anthropological records'. What this suggests, then, is that ' $[t]$ he story of the Reformation cannot be told accurately without taking into account the role that many remarkable women played during this time' (Potgieter 2016:8); otherwise it is simply a patriarchal reformation that needs reformation itself.

It also suggests that all the reformers, Ulrich Zwingli, Martin Luther and especially John Calvin, to whom much attention will be given, are an expression of a revolution of faith that is patriarchal. Laguzia (2017:5) observes the contradiction demonstrated by Calvin and Luther, who 'respected and loved women as ones created equal to them ... and as wives

3.See also Vellem's argument on this in his recent paper (2018:3): "The spiritual dimension of embracing the cross'.

4.For the term 'triple jeopardy', see Kobo, F.A. (2018:1), 'A womanist exposition of pseudo-spirituality and the cry of an oppressed African woman'. 
and mothers to their children', and yet failed to translate that love in the context of church leadership, which they believed was a man's duty and commitment.

\section{Laguzia (2017) further explains this contradiction:}

They used biblical injunctions about women's subordination to discourage women from assuming leadership positions in the church. The Bible and the Christian tradition were used to encourage women to find 'total womanhood in submitting themselves to their husbands.' For example, according to Calvin, women's subjugation is a matter of divinely appointed social 'office' in the order of creation. When a woman accepts her place she can be the good 'wife' ... but when she wishes to teach in the church, live her life independently or have authority over men, she subverts the social order and brings chaos and sin into the world. (pp. 5-6)

Laguzia's insights are telling for our conversation. The Bible and Christian tradition are used to justify the place a woman must keep in the church, a matter that continues to impact the role of women in churches to this day. While there seems to be nothing much from Zwingli's own writings that portray his attitude towards women:

$[H]$ is view of women seemed more in line with traditional views than with those of some of the humanists of his day. He echoed St. Paul in stating that the greatest adornment of a woman is the ability to keep silent' and he appeared somewhat arbitrary when he wrote that in Scripture prophesying means 'listening to sermons'. (Furcha 1992:135)

Martin Luther (2005) publicly expressed his attitude towards women in his works as 'weaker beings' who had to be silent in church:

$[T]$ he Holy Spirit has accepted women for all roles, but chooses competent men for pastoral role because women were required to keep silent in the church (1Cor. 14:34) and as weaker sex (1Pet. 3:7), cannot and shall not occupy positions of sovereignty, as experiences also suggests and as Mosses [sic] says in Genesis 3:16, 'you shall be subject to man.' Therefore, women do not qualify to pastoral office. (pp. 369-70)

However it is not surprising to see how Luther, Calvin and Zwingli use the Bible and Christian tradition, albeit in different ways, to justify their views, which turned out to be universalised. The patriarchal nature of the Reformed tradition is not a matter to dwell on, but the argument is rather to focus on its transmission to the African continent and where it positions a black woman.

Ramón Grosfoguel (2013), in his work entitled 'The Structure of Knowledge in Westernized Universities: Epistemic Racism/Sexism and the Four Genocides/Epistemicides of the Long 16th Century', resonates with our argument. He critiques the fact that a few men from five countries in Europe became the centres of the world's knowledge systems. He further argues that if one brings in aspects of social and historical experiences as sources of worldview in the conceptualisation of theory, then the contribution of these men is arguably provincial but disguised as universal.
Grosfoguel contends that the Social Sciences and the Humanities in Westernised universities are founded on the social theories based on the social experiences of these men. The implications are that other epistemologies are seen as inferior or not part of the canon, for example, non-Western, Global South knowledge systems. He observes that women's epistemologies are in the worst position, as they are inferior and outcasts to the canon of thought (Grosfoguel 2013:75). The relationship between Grosfoguel's argument and our conversation is that the Reformation is part of the Long 16th Century. ${ }^{5}$ The so-called discovery of the New World cannot be discussed without listing the Reformation as part of the package of the changes that took place in that century. Indeed, the transatlantic slave trade, symbolised by the ruthlessness of the Elmina Castle, is part of this order, which saw the Reformation as part of its religiosity. The knowledge and spiritual heritage of the enslaved peoples became a casualty of this new order of the Long 16th Century.

Vellem also points out the subversion of black and African epistemologies in his exposition of Tiyo Soga, whose lived experiences at the crossroads of AmaXhosa in South Africa and the West in Scotland speak to theological, sociological, political and economic knowledge forms that cannot be delinked from modernity. Of Soga, Vellem (2016:2) says, 'He is an embodiment of a life lived on the underside and shadows of Western constructs of knowledge'. In the same way this knowledge was embodied through a black woman in the dungeons of Elmina, a life shattered on the underside and shadows of Western constructs of knowledge, religious and theological knowledge, for that matter. In the context of Luther and others, namely the religious sphere, they arguably succeeded in passing to the world their views, cultures and experiences as universal.

The implications of this universalism in Africa resulted in the colonisation and enslavement of many black Africans and especially women. Their views and culture, when translated to Africa, led to the killing of many and the eradication and denigration of anything African (Biéler 2005; Njoh 2006; Oduyoye 2001; Shani 2014). Nelson Maldonado-Torres (2014) observes the link between the indoctrination of Africans with Western Christianity and their subservient role as 'good slaves'. There is ample evidence that supports the characterisation of the Reformation and Reformed tradition as racist and sexist when translated to Africa, as posited by Biéler (2005), Grosfoguel (2013), Maldonado-Torres (2014), Njoh (2006), Oduyoye (2001), Shani (2014), Tshaka (2014) and Vellem (2013).

The pertinent question for the researcher, who is by default a Calvinist, is whether John Calvin, to whom we shall turn

5.'The Long 16th Century, is explained by Ramon Grosfoguel (2013) as follows: "The Long 16th Century is the formulation of French historian, Fernand Braudel, who has Long 16th Century is the formulation of French historian, Fernand Braudel, who has influenced the work of world-system scholar, Immanuel Wallerstein (1974). It refers to the 200 years that covers the period between 1450 and 1650 . This is the period of the formation of a new historical system named by Wallerstein as the Modern World-System, or the European World-Economy, or the Capitalist World-Economy. The historical process that formed this new system covers the 200 years of the lon 16th century. I will use Long 16th Century to refer to the long durée processes that cover the initial formation of this historical system and use the term 16th century to refer to the $1500 s^{\prime}$ (p. 74). 
now, knew and was aware of Elmina, the slavery of black humanity and the female dungeons that cannot be delinked from the Reformed tradition and thus the racist and sexist Reformation?

\section{John Calvin}

The sexist and patriarchal nature of the Reformation has been demonstrated. It is necessary to focus on John Calvin because of his influence towards the experience of black women in the UPCSA and the history of apartheid in South Africa. 'Calvin can be held perhaps more accountable than other Reformation theologians for Protestant women's continued subordination to men in the church' (Douglass 1985:10).

Like Luther, Calvin's views and attitude on women are portrayed in some of his writings. In his commentary on 1 Timothy 2, he demonstrates his contradictions by arguing that God created women to be taught by men as subjects and to be silent and 'to keep within their limits and the condition of their sex' (Echoes from the Past 2008).

What is problematic about Calvin's truncated reading and interpretation of the Bible is how it became a universal way of reading and interpretation. Its implications have bearing on how women's leadership and teaching continue to be contested. It has even deadlier implications for black African people and especially women, who have had to contest for their own existence in a racist and sexist society. And if this truncated reading and interpretation of the Bible were to be exonerated it becomes toxic and sexist; it becomes a total toxic system that not only colonises men but puts a black woman in the dungeons of Elmina. ${ }^{6}$ It has already been submitted that Calvin likely knew and was aware of Elmina and the enslavement of black humanity as an aftermath of 'the discovery of new lands in Africa ...' (Biéler 2005:148), which cannot be delinked from 'forms of killings associated with violence and spirit of conquest' (Vellem 2016:1).

André Biéler (2005), a theologian and economist (also a conscious Reformed pastor), whose doctorate was on the study of economics on John Calvin's doctrine and practices, critiqued the churches of the north's social responsibility and engagement with those of the south on decolonisation. He offers a lengthy exposition on Calvin's teachings on slavery, which according to Vellem (2013) are an attempt to exonerate him. Biéler (2005) asserts that Calvin was aware of slavery and other related events of his time but was preoccupied with many things, and slavery was but one of those. He cites Calvin's sermon on Deuteronomy as one way in which he addressed and spoke against slavery. He also makes reference to Calvin speaking about slavery as contrary to God's natural order and Christian ethics and thus declaring it a 'visible and

6.One of the best expressions of toxic biblical interpretations is the title of the book by Phyllis Trible (1984), which suggests that the Bible is a text of terror. From the perspective of South Africa, the the that the Bible is a text of terror. From the perspective of South Africa, the terror caused by the Bible is at the centre of black reflection on statements such as the well-known "when the missionaries came, we African people had the land and they had the Bible. They said, "Let us pray", and when we opened our eyes after the prayer, they had the land and we had the Bible' (cf Saayman, W. 1998.153). The land issue for black people in South Africa and women in particular surely remains a poisoned chalice whenever it is interpreted through Eurocentric eyes. odious consequence of $\sin ^{\prime}$ and 'comparable to murder' (Biéler 2005:149, 151).

Biéler (2005) writes:

Social life within the early Christian church did in the end cause the total suppression of slavery in ancient society. Then in the eighteenth and nineteenth centuries the pressure brought to bear by Christian communities, particularly communities of Calvinist origin, brought about the abolition of modern enslavement of the blacks. (p. 152)

Vellem's critique of Biéler is helpful because it raises pertinent questions on the 'close affinity of the Reformed faith with slavery', which continues till this day. Vellem (2013) contends that:

[T] he good exposition of Calvin will forever have to contend with the practical distortions and death-dealing experiences of Black African peoples. Similarly, the South African contradictory versions of the racial, oppressive experiences of many a Black person have been explained as being consequences of the distortions of Calvin's teachings and thus the Reformed tradition itself. (p. 2)

Vellem's argument is indeed helpful as it brings to focus the reason why we should also look at Calvin and the Reformed faith in the dungeons of Elmina, the odour and broken bodies of black women. When we look at Calvin's theology, therefore, it is indeed difficult to comprehend and to some extent to 'exonerate' him for having said very little about the transatlantic slave trade in relation to the dungeoning of black women. It remains a continuous puzzlement for a womanist and any other person who has experienced Calvinism from the dungeons of Elmina to distinguish between the praise of Calvin and the negative sentiments about Calvinism. The teachings of Calvin are unrelated to the lived experiences of black women in the dungeons of Elmina, and this for us remains a criterion for the interpretation of this faith or tradition.

\section{Close affinity of the Reformed faith with the enslavement of a black woman}

Vellem's (2013) insights on the 'close affinity of the Reformed faith with slavery' and his reference to the first ordained black men are helpful for us. Vellem (2013) argues that:

Earlier in Ghana, the close affinity of the Reformed faith with slavery is depicted in the life of Jacobus Elisa Johannes Capitein ... an African child who was sold at the age of seven and later became a chaplain in the 18th century of the slavery-infested West Coast of Africa. (p. 2)

Vellem (2016) also makes reference to Tiyo Soga, the first black man to be ordained as a minister of Word and Sacrament in Scotland by the United Presbyterian Church of Scotland in 1856 (Duncan 2018; Njeza 2000). Tiyo Soga's marriage to a white woman from Scotland is for Vellem (2016:2) a demonstration of the 'quintessential epitome of the insult 
and degradation borne out of an encounter of Reformed faith by Black people'. His marriage to a white woman is symbolic of 'an encounter of Reformed faith by Black people' (p. 2), in the sense that it dislocates him from the dungeons and his people while speaking to his pseudo-agency.

Tiyo Soga, for Vellem, is a 'model', 'the model African we must imitate, an inspiration for us to be part of a Reformed Church in Africa' (2013:2). He is 'a model of the ambivalent experience of blackness and the conundrums of modernity in Africa' (2016:2). He further states that Tiyo Soga's was a life 'lived in crossroads' (2016:2). Tiyo Soga is a model because he was the first black ordained minister to experience the contradictions of Christian faith and its relationship with the conquest and colonisation of black people. The first of the women who experienced the Elmina dungeons, who were branded, chained, enslaved and sailed across the Atlantic, is therefore a model. Blackness is a life lived in ambivalence. Womanism is a life lived in ambivalence. 'Ambivalence' is a term that is central in Cone's theology; it is a state of paradox that is created by colonialism and the Reformed faith's complicity in the conquest of black people.

Indeed, Vellem's reference to Tiyo Soga as 'the model' (2013 and 2016) and his reflections on the dungeons shape how he views Calvin and the Reformation itself. Vellem (2013) avers:

I cannot but reach Calvin and Geneva through Tiyo Soga and through the dungeons that kept Jacobus Elisa Johannes Capitein and his forebears under a Reformed Church building in Ghana. (p. 2)

Vellem indeed exposes the links between Reformed faith and slavery and by implication racism, sexism, patriarchy, violence and thus the destruction of knowledge and spiritual heritage of black people. His use of Tiyo Soga and the dungeons, specifically Jacobus Elisa Johannes Capitein, inspires and frames a womanist interpretation of Reformed faith pursued in this article. While he cannot but reach Calvin and Geneva through Tiyo Soga, as womanists, we cannot but reach Calvin and Reformed faith through the bodies of black women in the dungeons of Elmina.

Without denying Vellem's commitment to the liberation of black women, I take issue nonetheless with the fact that in his article that reflects on the Reformed faith alluding to Elmina Castle, he names only male slaves to rightfully portray the harshness of the Elmina dungeons. My point is that there is a sense in which patriarchal violence has a tendency to elude black theologians. How much more then could this thing patriarchal violence - have eluded Calvin if indeed racism is an undergirding ideology that found justification through his own teachings?

In his works on being African and Reformed, Rothney Tshaka attempts to marry the two notions that have for years been foreign to one another. He posits that '[T]he African Reformed Christian must acknowledge its status as a partial outsider in Reformed theological discourse' (2014:1) and thus calls for a critical consideration of Africanness and Africanity (Tshaka 2007, 2009).

Tshaka contributes to an earlier point by Grosfoguel and Vellem on the subversion of African epistemologies by the Western canons of knowledge. He argues that 'In essence, like so many other mainline church traditions, Reformed theology had imposed its methodologies indiscriminately, without seeking ways of learning from the African situation"' (Tshaka 2014:5). He contends that 'African and Reformed theology need to acknowledge a particular history that in essence contributed towards a flight from the black self' (p. 5).

\section{Tshaka (2014) avers:}

The race question, which undoubtedly includes issues of culture and African world views, is therefore a significant aspect in our drive to halt the flight from the black self. The issue of race is deeply entrenched in the psyche of South Africa. This is evidenced by the literature, which pointed to both the establishment of racist tendencies in South Africa and the means undertaken to safeguard that particular racism. It is therefore not by chance that challenges, which are in some instances preventable, are the same challenges that contribute to the destruction of Africans. (p. 6)

That there is a relationship between racism and the Reformed faith as demonstrated by Tshaka's aforementioned views is undeniable. The Reformed faith has tremendous implications for the cultural understanding of black humanity as it has arguably contributed to the flight from the black self. It also has implications in the drive to halt this flight from the black self and to confront the deeply entrenched racism in the psyche of women and black South Africans in general. This article argues that it is necessary to go where this tragic history actually started, the dungeons of Elmina Castle. Often, the entrenched psyche of racism in South Africa is traced to apartheid, yet in this article apartheid is linked to the Long 16th Century - and that's the dungeons of Elmina as a historical starting point of the justification of the commodification of life.

What Tshaka is saying about black humanity is that the flight from the black self started in Elmina Castle in 1492. Elmina depicts the colonisation of black humanity and violence against black women in its dungeons. Yet from the perspective of a womanist, the apparent emphasis on one of the constructs of colonisation such as racism without similarly emphasising the plight of women, which synchronised with all the ills of colonialism, is a critical question a black theology of liberation must deal with. Liberation has to be comprehensive. Any truncated approach to liberation is dangerous for black humanity as a whole.

The affinity of the Reformed faith with the enslavement of black people is a point well made, but the experience of a black woman as embodied in the dungeons of Elmina seems to be often occluded by black theologians. There were women in the dungeons and they resisted while chained, branded and throttled in the dungeons at the same time as the 
enslaved men. This is important to recognise to respond to a faith tradition that was sexist, patriarchal, racist and violent.

\section{Pervasive dungeoning of South African black women post-1994}

I was sent by the UPCSA as one of the delegates to a consultation of Reformed churches in the Southern Africa Region whose aim was to establish themselves as a subregion of the Africa Communion of Reformed Churches, an African region of the World Communion of Reformed Churches. It was held in Emseni Conference Centre, in Benoni, from 22 to 24 March 2018. The delegation was comprised of moderators and general secretaries of these churches, who were all men, except for a few women who were requested to be 'administrators'. I was also requested to be one and refused as a form of protest.

On the first day of the consultation the conversation started on gender justice. The programme was nonetheless nonrepresentative. ${ }^{7}$ A number of reasons and excuses for why women were not represented were given. Some gave appalling reasons like, 'it is difficult to find good women to represent the church' (22 March 2018). Professor Rothney Tshaka was one of the presenters in the consultation. In response to a question that I posed that reflected on the location of black women in the Elmina dungeons and on the possibility therefore of the Reformed faith and churches ever transforming, when their delegates were all male in a consultation in 2018, Prof. Tshaka acceded that patriarchal violence and the experience of black women seems to be often occluded by black theologians themselves. She argued that this is a question that must continue to be raised (23 March 2018).

If it is difficult to find good women to represent the church as suggested by the participants in this consultation, one can ask, find them where when they are in the dungeons in Elmina? Perhaps this statement or question as to where good women can be found, as a response to the inadequate participation of women in that particular conference, is a subtle question in church structures and society to justify the patriarchal exclusion of women from participation. To say 'find them in Elmina' is not a literalistic response to this question but indeed represents the place of a black woman in perpetual, systemic impoverishment of black women culturally, anthropologically, theologically and otherwise. That the main presenters were white men, black men and a white woman is exactly an expression of the transversal nature of racism to which womanism responds. Womanism is a response to racist power structures of both white men and women and patriarchal violence by black men. Womanism is a response to anthropological pauperisation, articulated as follows:

The social underdevelopment of Africa represents a fundamental aspect of the anthropological pauperisation of the African person.

If we define pauperisation as the fact of becoming or making poor, namely being deprived of all that we have acquired, all that we are and all that we do, we shall recognise that Africa is subjugated to structures which result in complete pauperisation: political, economic, and social. When it is not a matter of being deprived of all that we own, but rather of all that we are - our human identity, our social roots, our history, our culture, our dignity, our rights, our hopes, and our plans - then pauperisation becomes anthropological. It then affects religious and cultural life at its very roots. (Dedji 2003:258)

A further illustration of the dungeoning of black women is an invitation to celebrate four decades of women's ordination at the General Assembly of the denomination, which was sent by the clerk of the assembly to all ordained women in our denomination. The setting of the agenda by excluding women and yet the response of the UPCSA to patriarchal violence remains suspect. This was received with mixed emotions by women themselves as we engaged through text messages, phone calls and emails. Some of the questions raised by different women are: who is inviting? Who is being invited? Who said we want to celebrate? Why we were not consulted? Why do they speak on our behalf? Why do they invite us to celebrate when we have congregations that will never call ordained women to be their ministers? Why must we celebrate in a church that clearly does not want us?

That the denomination has decided to celebrate us without engaging us is indeed a sad story of the 21st century. There was never an anniversary to celebrate women in the UPCSA and without women having called for it, it remains a suspect patriarchal agenda. They have invited as a keynote speaker the first black woman to be ordained in our denomination, the Rev. Charity Majiza, who recently retired from 39 years of ministry at Echuca Moama Uniting Church, in Australia. Rev. Majiza left South Africa in the early years of her ordination, traveling to Scotland then Australia, where she spent 18 years before returning to serve as the General Secretary of the South African Council of Churches in 1997 (Chapman \& Spong 2003). She later returned to Australia and is married to a white Australian. She describes herself in the following way:

I am a third-generation Christian; my family was among the first people who received missionaries from the Church of Scotland in the 1840s when they came to the Eastern Cape in South Africa. I am part of the delegation from the Uniting Church in Australia (UCA), whose previous denominations sent missionaries to the Asia-Pacific region and to remote parts of Australia: a church that welcomed me as a stateless person, a refugee and an ordained woman from Africa. (Majiza 2010:14)

Charity Majiza, as the first ordained black minister in the former Reformed Presbyterian Church in Southern Africa (RPCSA), now a constituent part of the UPCSA, did not stay in the church; she left for Australia. More importantly, when she came back to South Africa, as the first woman to become the General Secretary of the South African Council of Churches (SACC), she did only one term of her appointment and went back to Australia. While we appreciate her as a person, her invitation however is an illustration of the co-optation of women in the agenda that is not theirs. 


\section{Pseudo-spirituality of a Calvinist woman from the dungeons of Elmina}

Kobo's (2018) work entitled 'A womanist exposition of pseudo-spirituality and the cry of an oppressed African woman' is helpful for us. In this article she looks at the cries of African women in juxtaposition to their prayers, faith and thus spirituality and argues that theirs is a pseudospirituality. ${ }^{8}$ She points to contradictions maintained by the Women's Manyano, a site where women from $^{9}$ the UPCSA gather for prayer meetings and liturgical practices, a space where even the patriarch rules (Kobo 2018:5). ${ }^{10}$ She argues that women's spaces are patriarchal and women are androcentric vessels of patriarchy.

Pointing at the assumption of headship theology and how women become legitimisers of their own dominations, the article exposes the tensions that arise when women occupy leadership positions in the church and other spheres, as well as the disjuncture between being a leader and being a woman. She argues that between leadership and being a woman one has to collapse and, in most instances, the latter collapses (2018:5). For instance if one looks at one of the illustrations of this collapse as demonstrated by Kobo (2018), it is telling that the Women's League of the African National Congress in the recent electoral conference of this political organisation missed an opportunity to put into power the president and the deputy president of this organisation, given the fact that they are in majority as women. That women would easily participate in structures that take decisions that oppress them is a rampant occurrence that easily finds expression in almost all spheres. Their pseudo-spirituality arguably emanates from the dungeons. Black women can only be reformed if they understand what the dungeons are all about. However, because even Calvin himself and Reformed faith missed the meaning of the dungeons for black people and especially women, reformation and the Reformed faith will continue to produce pseudo-spirituality.

The demise of Winnie Madikizela-Mandela poses questions about the dungeons that refuse to die. While her commitment to the struggle is acknowledged, newspapers however qualify it with statements like 'the triumph over apartheid was "overshadowed by scandal"', 'Madikizela-Mandela went from "mother to mugger" of democratic South Africa' and for others she has been reduced to nothing more than the late Nelson Mandela's ex-wife (Panther2018). Her commitment has also been ghettoised by women themselves, who fail to translate the onslaught on Winnie to a patriarchal society's hypocrisy that has embraced the evils of men in leadership and is now reminding Winnie that she is a woman! Her grave, a dungeon therefore! The speeches by Julius Malema (Andersen 2018) ${ }^{11}$ and Zenani Mandela-Dlamini

8.For more insights on pseudo-spirituality see Kobo (2018:2).

9.For more insights on Manyano see Kobo (2018:2).

10.For more insights on space allocated to women but ruled by patriarchs, see Kobo (2016).

11.https://www.thesouthafrican.com/malema-winnie-mandela-funeral/, viewed 27 April 2018.
(Dlamini 2018), Winnie's daughter, at Winnie MadikizelaMandela's funeral nuance this. Kimberley Yates has long commented on the demonisation of Winnie as a ploy to erase her from the history of our struggle in South Africa, even when she was still alive (Yates 1998).

\section{A womanist reflection on Christ's encounter with a woman at the margins}

I reflect briefly on the Bible study that I presented entitled 'A slave amongst slaves: A womanist reading of Mark 5:21-34' in Elmina in January 2018, to draw vital points as contributions to a womanist discourse. Two ideas from verse 30, namely, 'loss of power' and 'turning around and the implication for those in Elmina, Benoni and the UPCSA' frame my brief reflection.

\section{Firstly, Jesus lost power!}

Jesus cannot stop the bleeding if he remains powerful. Salvation is nothing else but the powerful powerlessness of Jesus! There are many churches today that have usurped the cross of Jesus. The God of the oppressed is powerless: 'For the foolishness of God is wiser than human wisdom, and the weakness of God is stronger than human strength' (1 Cor 1:25). Our salvation is in powerlessness. From a womanist perspective, one can argue that Christianity has become a religion of the powerless. In their reflection of who Christ is for African women, Oduyoye and Amoah (1989) observe how Christ chooses the side of the poor, the marginalised and the outcasts - how he liberates them from 'the burden of disease and the ostracism of a society riddled with blood taboos and theories of inauspiciousness arising out of women's blood' (p. 43).

\section{Secondly, Jesus turned around!}

He was moved! He is moved by the bleeding and the cry for life of slaves among slaves, that is, the poor, the oppressed, the outcasts and the marginalised. In being a church of Christ, Jesus is calling us to turn around, in contrast to being those that turn others around when we have not been turned around! Being turned without turning others. Church that cannot be turned around. Ecclesiology that cannot be turned around and un-turning theologies! Womanists pose the following question: Is Christianity that cannot be turned around true to the liberating gospel of Jesus?

The contribution of a womanist discourse could therefore be to turn upside down the Elmina complex of the colonial wound. It proposes a restructuring of Elmina, Benoni and the UPCSA as follows:

- dungeons on top

- merchants, galleries, governors' quarters and Reformed Church below.

'Dungeons on top' represents a bleeding woman that is always concealed in the church. The current church hides 
the dungeons underneath and pretends that they do not exist. The experiences of women in the dungeons as our starting point can be our only beacon of hope. Without that, the relevance of Western Christianity, reformation and the Reformed tradition remains eternally toxic to the consciousness and spirituality of a black African woman. To reiterate an earlier point, any interpretation of Reformed faith without black bodies in dungeons means nothing for womanists.

\section{Womanism: An irruption from the dungeons}

What can I as a Reformed black African woman celebrate except black African women in dungeons who are rebels? ${ }^{12}$

Reformed from the dungeons

Reformed from the smells, the branding and odour of the black woman

Reformed from the gate of no return

Reformed from under the barracks of Reformed clergy

Reformed from rapists and merchants

Reformed from 'good men'

Reformed from being celebrated by men, 'good men'

Reformed from Western Christianity

Reformed from the Bible

Reformed from a racist/sexist Reformation

Here we have a lamentation for those women who resisted being raped in Elmina Castle. A lamentation by those who refuse to be dungeoned in South Africa post 1994, in Benoni, in the UPCSA and in all spheres of society. Reformed womanists!

\section{Conclusion}

The article interprets Reformation theology through the eyes of Elmina Castle in Ghana as the genesis of the dungeoning of black women justified by faith. We submit that John Calvin was aware of Elmina and the dungeoning of black women, but in his theology and teachings missed the meaning of the dungeons and its implications for Reformed faith, a Reformed faith that produced and continues to produce pseudospirituality, found in pervasive dungeons for South African women post 1994. By bringing Calvin and the Reformed faith into the dungeons, we are taking black women out from the dungeons.

By placing the dungeons on top, a womanist perspective challenges the structural injustices in the Reformed faith and churches. It calls for their radical restructuring and transformation. Without that, the relevance of Western Christianity, reformation and the Reformed tradition remains eternally toxic to the consciousness and spirituality of a black African woman. As it stands, there cannot be a reformation that is attributed to Zwingli, Luther and Calvin, or even men who have fought against distortions of Calvinism itself in the struggle against apartheid in South Africa, without the denigrated body of a black woman in the dungeons of Elmina being brought to the top.

\section{Acknowledgements Competing interests}

The author declares that he or she has no financial or personal relationships which may have inappropriately influenced him or her in writing this article.

\section{References}

Andersen, N., 2018, 'Watch: Malema's full fiery tribute at the Winnie Mandela funeral [video],', The South African, viewed 27 April 2018, from https://www. thesouthafrican.com/malema-winnie-mandela-funeral/

Bowie, F., Kirkwood, D. \& Ardener, S., (eds.), 1994, Women and Missions: Past and present anthropological and historical perceptions, Bloomsbury, Oxford.

Biéler, A., 2005, Calvin's economic and social thought, World Council of Churches, Geneva. PMCid:2212915.

Chapman, A.R. \& Spong, B., (eds.), 2003, Religion and reconciliation is South Africa. Voices of religious leaders, Templeton Foundation Press, Philadelphia and London.

Dedji, V., 2003, Reconstruction and renewal in African Christian Theology, Acton Publishers, Nairobi, Kenya.

Dlamini, Z., 2018, 'Read Zenani Dlamini's speech in full', Mail \& Guardian, viewed 27 April 2018, from https://mg.co.za/article/2018-04-14-read-zenani-mandeladlaminis-speech-in-full

Douglass, J.D., 1985, Women, freedom and Calvin, The Westminster Press, Philadelphia.

Duncan, G.A., 2018, 'Tiyo Soga (1829-1871) at the intersection of "universes in collision"', HTS Teologiese Studies/Theological Studies 74(1), 4862. https://doi. org/10.4102/hts.v74i1.4862

Echoes from the Past...Reflections for the Present, 2008, 'John Calvin on Women in Leadership', viewed 28 March 2018, from https://echoesfromthepast.wordpress. com/2008/09/04/john-calvin-on-women-in-leadership

Furcha, E. J., 1992, 'Women in Zwingli's World', Zwingliana 19, 131-42.

Giselbrecht, R.A., 2014, 'A hermeneutic of female testimony in the Zurich Reformation (1518-1575)', PhD thesis, Fuller Theological Seminary.

Grosfoguel, R., 2013, 'The structure of knowledge in Westernized Universities: Epistemic Racism/Sexism and the Four Genocides/Epistemicides of the Long 16th Century' Human Architecture: Journal of the Sociology of Self-Knowledge 11(1), 8, viewed from http://scholarworks.umb.edu/humanarchitecture/vol11/ $11(1), 8, v i$
iss $1 / 8$

History.com Staff, 2009, 'The Reformation', viewed 27 March 2018, from http://www. history.com/topics/reformation. A + E Networks.

Kobo, F., 2016, 'Umfazi akangeni ebuhlanti emzini ... A womanist dialogue with Black Theology of Liberation in the 21st century', HTS Teologiese Studies/Theological Studies 72(1), a3268. https://doi.org/10.4102/hts.v72i1.3268

Kobo, F.A., 2018, 'A womanist exposition of pseudo-spirituality and the cry of an oppressed African woman', HTS Teologiese Studies/Theological Studies 74 (1), 4896. https://doi.org/10.4102/hts.v74i1.4896

Laguzia, F., 2017, 'Reformation is Germane to African Women: An African Lutheran Woman's Imagination', Consensus 38(1), 13, viewed 28 April 2018, from http:// scholars.wlu.ca/consensus/vol38/iss1/13

Luther, M., 2005, 'On the Councils and the Church', in T.F. Lull (ed.), Martin Luther's basic theological teachings, pp. 369-70, Fortress Press, Minneapolis.

Majiza, C., 2010, Unity and mission, The ecumenical review, World Council of Churches, Geneva.

Maldonado-Torres, N., 2014, 'AAR Centennial Roundtable: Religion, Conquest, and Race in the Foundations of the Modern/Colonial World'. Journal of the American Academy of Religion 82(3), 636-665. https://doi.org/10.1093/jaarel//fu054

Njeza, M.M., 2000, 'Subversive subservience: A comparative study of the responses of Tiyo Soga and Mpambani Mzimba to the Scottish missionary enterprise', PhD thesis, University of Cape Town.

Njoh, A.J., 2006, Tradition, culture and development in Africa: Historical lessons for modern development planning, Ashgate Publishing Ltd., Hampshire, England.

Oduyoye, M.A. \& Amoa, E., 1989, 'The Christ for African women', in M.A. Oduyoye \& V. Fabella (eds.), With Passion and Compassion: Third World women doing theology, pp. 35-45, Orbis Books, Maryknoll, NY.

Oduyoye, M.A., 2001, Introducing Women's Theology, Sheffield Academic Press, Sheffield. 
Panther, R., 2018, 'Even in death, Mam' Winnie can't catch a break', Mail \& Guardian 03 April, 2018, viewed 08 April 2018, from https://mg.co.za/article/2018-04-03in-death-mam-winnie-has-rallied-her-mourners

Potgieter, R., 2016, 'Anna Reinhard Zwingli - "Apostolic Dorcas", "dearest housewife", "angel-wife", "ziel van mijn ziel" and "mater dolorosa of the Reformation": From woman to valued citizen', In die Skriflig 50(3), a2007. https://doi.org/10.4102/ids. v50i3.2007

Saayman, W., 1998, 'Ownership of land and Christian mission in South Africa: erecting signs of hope', in D.S. Gillan (ed.), Church, land and poverty. Community struggles, land reform and the policy framework on church land, pp 153-157, The South African Council of Churches, the National Land Committee, The Church Land Project and The Surplus Peoples's Project, Johannesburg, South Africa.

Shani, G., 2014, Religion, identity and human security, Routledge Studies in Religion and Politics, Routledge, New York.

Trible, P., 1984, Texts of terror: Literary-feminist readings of biblical narratives, Fortress Press, Philadelphia.

Tshaka, R.S., 2007, 'African you are on your own! The need for African Reformed Christians to seriously engage their Africanity in the Reformed Theological Reflections', Scriptura 96(3), 533-548.
Tshaka, R.S., 2009, 'Academic theology as the yardstick of being reformed in South Africa today: An appreciative critique of Calvin on the occasion of his $500^{\text {th }}$ birthday', Studia Historiae Ecclesiasticae XXXV, 1-16.

Tshaka, R.S., 2014, 'On being African and Reformed? Towards an African Reformed theology enthused by an interlocution of those on the margins of society', HTS Teologiese Studies/ Theological Studies 70(1), Art. \#2070, 7 pages. https:// doi.org/10.4102/hts.v70i1.2070

Vellem, V.S., 2013, 'The Reformed tradition as public theology', HTS Teologiese Studies/Theological Studies 69(1), Art. \#1371, 5 pages. https://doi.org/10.4102/ hts.v69i1.1371

Vellem, V., 2016, 'Tiyo Soga: Violence, disruption and dislocation in the white polis' HTS Teologiese Studies/Theological Studies 72(1), a3563. https://doi.org/10.4102/ hts.v72i1.3563

Vellem, V., 2018, 'The Spiritual dimension of embracing the cross', Conference on World Mission and Evangelism, Arusha, Tanzania, March 8-13, 2018, Doc. No. PLEN 06.4.

Yates, K., 1998, 'Attacks on mother Africa: mass media and their coverage of Winnie Mandela', paper presented at the First African Womanist Workshop, University of Cape Town, Cape Town, 23 January. 